\title{
Konstruowanie tożsamości w Internecie - młodzi ludzie z niepełnosprawnością intelektualną
}

\author{
Rafał Maciąg \\ (D) https://orcid.org/0000-0003-2571-2517 \\ Warszawski Uniwersytet Medyczny
}




\title{
Streszczenie
}

Konstruowanie tożsamości $\mathrm{w}$ internecie przez młode osoby $\mathrm{z}$ niepełnosprawnością intelektualną przebiega nieco inaczej niż u innych uczestników sieci. Według badań korzystają oni z komunikacji online, lecz na ogół poznają różne udogodnienia i nowinki z pewnym opóźnieniem. Celem rozważań jest zatem odpowiedź na kilka pytań: jaki wpływ ma internet na różne aspekty życia niepełnosprawnych intelektualnie, na podejmowanie ryzyka, na samotność i nawiązywanie kontaktów, poznawanie życia seksualnego a także na rolę rodziców (np. Seale, Chadwick, 2017). Młodzi ludzie z niepełnosprawnością intelektualną korzystają z internetu w nieco innych celach niż większość społeczeństwa. Jak się okazuje, bardzo ważne jest samo utrzymywanie kontaktu z innymi w sieci w celach emocjonalnych (Krzyżak-Szymańska, red., 2019). Niepełnosprawność intelektualna wytwarza dodatkowo sytuację, w której młodzi poddawani są częstszej agresji i hejtowi (Plichta, 2017). Mimo że tożsamość konstruowana w internecie pozwala na ukrywanie prawdziwego „ja” i nawiązywanie relacji będących namiastką normalności (Watson, 2002), to w rezultacie rzadziej dochodzi do realnych spotkań w porównaniu z grupami młodzieży bez problemów.

\section{Słowa kluczowe}

hejt, internet, komunikacja online, niepełnosprawność intelektualna, tożsamość.

\section{The construction of online identity - young people with intellectual disabilities}

\begin{abstract}
The construction of online identity by young people with intellectual disabilities is slightly different than in the case of non-disabled peers. According to research, they use online communication, but they usually learn about various amenities and news with a delay. The aim of the considerations is to answer the question of what impact the Internet has on various aspects of life: risk-taking, loneliness and networking, getting to know sex life, the role of parents (eg Seale, Chadwick, 2017). Young people with intellectual disabilities use the Internet for slightly different purposes than their peers. It is very important to maintain contact with others online for emotional purposes (Krzyżak-Szymańska (red.), 2019). Intellectual disability additionally creates a situation in which young people are subjected to more frequent aggression and hate (Plichta 2012). Although the identity constructed on the Internet allows to hide the real „I” and establish relationships that are a substitute for normalcy (Watson, 2002), as a result, real meetings are less frequent than among groups of able-bodied youth.
\end{abstract}

\section{Keywords}

hate, identity, intellectual disability, internet, online communication. 
B udowanie tożsamości u osoby z niepełnosprawnością intelektualną bywa procesem trudnym. Bariery w tym procesie stanowią reakcje społeczne na odmienność. Internet pozwala na konstruowanie jaźni za pomocą różnych narzędzi i portali, zwłaszcza wtedy, gdy tożsamość można zmieniać i w sposób plastyczny dopasowywać do okoliczności w świecie wirtualnym. Istnieją różne modele rozwiązań, na przykład takie, aby osobom niepełnosprawnym intelektualnie udostępniać internet $\mathrm{w}$ celu integracji z innymi (zob. Seale, Chadwick, 2017). Niepełnosprawni przeżywają ciągłą konfrontację z własnym „ja” cielesnym i/lub umysłowym, wiedząc, że nie do końca są akceptowani. W internecie czują się swobodniej, mogą nawiązywać znajomości, oderwać się od świata rzeczywistego. Przeszkodą do zbudowania integralnej tożsamości jest poczucie wykluczenia, czyli, jak pisze Goffman (2005), jednostka jest zraniona przez stygmatyzację i nadawanie etykiet. W przypadku korzystania z internetu proces ten bywa nieraz nasilony, gdyż wśród młodych występuje obrażanie, groźby, wyzywanie, ale też nękanie seksualne. Zapewniając przyjemność, internet oferuje wiele niebezpieczeństw. Dla osób z niepełnosprawnościami świat wirtualny stanowi jednak odskocznię od trudnej rzeczywistości. Izolacja i samotność jest bowiem środkiem zapewniającym bezpieczeństwo i chroniącym przed negatywnymi doświadczeniami ze strony rówieśników, autorytarnych nauczycieli i wymagających rodziców, a także przed ogólnie pojętą kulturą aktywności i sukcesu. Jak wykazuję dalej, dla osób z niepełnosprawnością intelektualną internet stanowi okno na świat i pełni nieco inne funkcje niż dla ich rówieśników.

Niepełnosprawność intelektualna jest definiowana przez różne zaburzenia normy zachowania lub zdrowia. Niektórzy badacze włączają do tej kategorii też spektrum autyzmu czy trudności w uczeniu się jako odbiegające od normy, czyli wszystkie „zachowania nietypowe” (Mróz, 2018). Dostępne badania koncentrują się przede wszystkim na niepełnosprawności intelektualnej w stopniu lekkim i dotyczą jednostek, które w miarę swobodnie komunikują się online i rozumieją swój status i miejsce zdefiniowane przez rodziców, lekarzy, terapeutów i nauczycieli.

W tym miejscu trzeba wyraźnie podkreślić dwie rzeczy. Pierwsza dotyczy kwestii metody prezentacji, którą niżej stosuję. Druga jest nie mniej ważna, gdyż dotyczy samej istoty badań nad korzystaniem z internetu przez osoby z niepełnosprawnością intelektualną.

Po pierwsze, prezentuję tutaj przegląd badań, w których wzięła udział młodzież z niepełnosprawnością intelektualną, a obejmują one ostatnie dwadzieścia lat. Jest to przegląd uwzględniający najważniejsze badania $\mathrm{z}$ tego zakresu, które zamieszczono w bazach czasopism naukowych Google Scholar i Pubmed. Trzeba wspomnieć, że badania tego rodzaju są wykonywane dość rzadko z powodu trudności metodologicznych w realizacji (o czym niżej). Wiek oraz rodzaj niepełnosprawności dzieci i młodzieży jest różny, a niektóre badania biorą też pod uwagę opinie rodziców. Jednym z ważnych kryteriów w tej analizie - ze względu na kształtowanie tożsamości - były założenia badawcze autorów: podejmowanie ryzyka, rodzaj komunikacji, zachowania agresywne i inne (Seale, Chadwick, 2017). Przy czym dla badaczy tego problemu rzadko kryterium badań stanowi samo pojęcie tożsamości, a raczej problemy niepełnosprawności intelektualnej i rozwojowej (IDD) 
i częstość korzystania z internetu. Dlatego tożsamość pozostaje tutaj raczej kategorią pojęciową, spajającą szeroką problematykę obejmującą obszar intellectual and developmental disabilities. Mimo wszystko studia te skupiają się na wspomnianych problemach, obejmujących z jednej strony ucieczkę w samotność, z drugiej zaś analizują stopień zaangażowania w cyberprzemoc i wykorzystywanie seksualne młodzieży niepełnosprawnej w sieci. Muszę zaznaczyć, że sam nie prowadziłem badań z tego zakresu, ale zainteresowania moje od jakiegoś czasu dotyczą zachowań młodzieży, interakcji w grupie zdrowych, chorych i niepełnosprawnych oraz zagrożeń, jakie może nieść zbyt częste zaangażowanie w gry internetowe (Maciąg, 2021).

Po drugie, warto zwrócić uwagę na pewne trudności metodologiczne występujące przy realizacji takich badań. Tożsamość osób niepełnosprawnych intelektualnie w dużym stopniu jest określana przez perspektywę medyczną. Jak wspomniano, pojęcie niepełnosprawności intelektualnej i rozwojowej jest zdefiniowane przez normy zdrowotne w klasyfikacji psychiatrycznej DSM-5 oraz wyznaczone w klasyfikacji rozpoznań ICD-10 (w nowej wersji - ICD-11). Niepełnosprawność intelektualną w stopniu lekkim wyznacza iloraz inteligencji w przedziale 50-70 punktów IQ Wechslera, przy czym rozwój intelektualny jest nieco opóźniony. DSM-5 traktuje niepełnosprawność intelektualną jako „zaburzenie, które zaczyna się w okresie rozwojowym i obejmuje deficyty w intelektualnym i adaptacyjnym funkcjonowaniu w obszarze koncepcyjnym, społecznym i praktycznym" (Amerykańskie Stowarzyszenie Psychiatryczne APA, 2013, za: Krzyżak-Szymańska, red., 2019, s. 14). Widzimy więc, że zmedykalizowane spojrzenie na tę sferę umieszcza jednostki w odpowiedniej kategorii dewiacyjnej.

Problemy metodologiczne badań opisuje kilku autorów. Są one bardzo istotne, gdyż poza metodologią dotykają kwestii etycznych. Jak pisze Grzegorz Całek (2020, s. 160), już badanie z rodzicami dzieci z Zespołem Aspergera tworzy trudności „wychodzenia poza relacje badacz-badany”. Przekształca się ono w długie spotkanie z osobą badacza: rodzic chce się wyżalić, mówiąc o własnych problemach, często to jemu zależy na takim spotkaniu bardziej niż badaczowi, ten ostatni występuje tu w nieokreślonej roli terapeuty. Nieco inne, ale dość podobne problemy metodologiczne opisują de Groot, Kaal, Stol (2019), a ich badanie jest o tyle znaczące, że na ogół inni badacze nie wymieniają trudności występujących we wstępnej fazie przygotowawczej pomiarów. Warto więc zauważyć, że w badaniu de Groota i in. uczestniczyła młodzież z niepełnosprawnością intelektualną w stopniu lekkim oraz z pogranicza tego stanu, gdzie zastosowano różne metody i techniki badawcze. Na ankietę online żaden z respondentów nie odpowiedział w pełni, gdyż wystąpiły trudności ze zrozumieniem przez nich wszystkich pytań. Gdy następnie przeprowadzono badania w grupach fokusowych wśród młodzieży i rodziców, duże trudności sprawiało samo tłumaczenie, do czego służy początkowy formularz zawierający zgodę na wzięcie udziału w badaniu. Dlatego najlepszym wyjściem okazało się badanie w postaci obserwacji uczestniczącej w domach uczestników oraz omawianie wysyłanych klipów. Dopiero takie podejście jakościowe pomogło zrozumieć motywacje młodych ludzi, którzy, jak się okazało, wysyłają zdjęcia w celach zaspokojenia napięcia emocjonalnego. Można mieć zatem wątpliwości co do wyników badań wykorzystujących narzędzia ilościowe. Istnieją jednak dowody, że ankiety, jak i grupy fokusowe, 
można stosować do badań nad niepełnosprawnością intelektualną (Didden i in., 2009; Douma i in., 2012). W przytoczonym badaniu de Groot i in. wykazali, że obserwacja $\mathrm{w}$ środowisku domowym nastręcza trudności etycznych (np. ujawnianie przez młode osoby kontaktów z dorosłymi, na co wcześniej rodzice nie pozwalali), traktowanie badacza jak bliskiego znajomego (zob. Całek, 2020, literatura tamże). Przytaczam te przykłady w celu zrozumienia trudności w realizacji takich badań, ale dla szerszego omówienia tematu będę opierał się też na innych pomiarach realizowanych za pomocą metod ilościowych. Większość badaczy w celach porównawczych wykorzystuje różnego rodzaju kwestionariusze.

\section{DOSTĘPNOŚĆ INTERNETU I PODSTAWOWE PROBLEMY}

Jane Seale i Darren Chadwick (2017) zastanawiają się nad ryzykiem, które może zajść, gdy udostępnimy w zasadzie bez ograniczeń internet dla osób z niepełnosprawnością intelektualną. Przeprowadzili oni analizę badań i doszli do wniosku, że „normalne korzystanie z internetu jest właściwe", a każde zachowanie, niezależnie czy dotyczy osób z niepełnosprawnością intelektualną, czy bez, regulowane jest normatywnie. Co więcej, niektóre zachowania cyfrowe są częściej nadużywane w sensie negatywnym przez osoby pełnosprawne intelektualnie, niż przez jednostki z lekkim upośledzeniem. „Normalne zaangażowanie w świat cyfrowy można postrzegać jako to, co zwykle i często dzieje się regularnie $\mathrm{w}$ określonym kontekście, tj. wszystkie zachodzące zachowania cyfrowe są normatywne" (tamże). Podejście to jest elementem szerszego nurtu włączania osób niepełnosprawnych, w którym bierze się pod uwagę kwestię ryzyka do praktyk wsparcia. Zakłada się przy tym, że dostęp do internetu w tym przypadku nadzorują opiekunowie, którzy monitorują, ile czasu niepełnosprawny korzysta $\mathrm{z}$ internetu w celach edukacyjnych, a ile i w jaki sposób poświęca na cyberrandki.

W tym miejscu należy uczynić dwa zastrzeżenia. Pierwsze dotyczy dostępu do internetu, który jest obwarowany różnymi barierami natury społecznej i zdrowotnej. Według Doroty Żuchowskiej-Skiby (2020, s. 198) niepełnosprawni rzadziej niż sprawni korzystają z internetu, a jeśli już, to częściej korzystają z internetowych informacji o usługach zdrowotnych, częściej też grają w gry i wykonują połączenia telefoniczne w internecie niż osoby zdrowe. Druga kwestia, o której wypada wspomnieć, to tzw. problemowe korzystanie $\mathrm{z}$ internetu, i nie dotyczy ono bynajmniej tylko osób niepełnosprawnych intelektualnie. Z badań Ewy Krzyżak-Szymańskiej (2019) wynika, że pewien odsetek młodzieży ze szkół specjalnych, która nadużywa w sposób problemowy internetu, zaniedbuje różne obowiązki, spóźnia się do szkoły, jest niewyspana, nie odrabia lekcji lub je opuszcza. Warto też wspomnieć, że kontrola rodzicielska nad korzystaniem z internetu jest zazwyczaj niewielka (większa ze strony matek niż ojców) i zależy od relacji i więzi z dzieckiem.

Osoby młode z niepełnosprawnością intelektualną na ogół rzadziej korzystają ze sprzętu komputerowego, telefonów oraz internetu od swych zdrowych rówieśników. Wyniki badania Ewy Krzyżak-Szymańskiej (red., 2019) wśród uczniów szkół specjalnych 
ujawniają dalej, ,że ponad połowa badanych co najmniej kilka razy w tygodniu korzysta z serwisów społecznościowych (61\% badanych), słucha muzyki lub radia online (59\% respondentów), komunikuje się z rodziną lub znajomymi poprzez sieć (58\% badanych) oraz wysyła lub odbiera elektroniczne wiadomości (56\% respondentów). Co dziewiąty badany deklaruje, że przynajmniej kilka razy w tygodniu odwiedza strony związane z seksem (11\% ogółu badanych), a co ósmy respondent czyta wiadomości np. na „Pudelku" (12\% ogółu badanych)" (Krzyżak-Szymańska (red.), 2019, s. 51). W gry komputerowe gra ogółem 59\% badanych, w tym 78\% chłopców i 22\% dziewcząt (tamże). Czas poświęcany na gry często przekracza 6 godzin w dni wolne od nauki, co zadeklarowało $26 \%$ uczniów szkół podstawowych. Interesujące dla dalszych rozważań są jeszcze zagrożenia, jakich obawiają się młodzi respondenci. Najbardziej boją się oni, że ktoś skradnie ich dane osobowe lub hasła, że będzie udawał „że jest mną" i publikował obraźliwe informacje, lub że wrzuci do internetu ich własne zdjęcie lub informacje, których nie chce się ujawnić. Najmniej młodzi boją się tego, iż rodzice dowiedzą się, co robią w internecie (tamże, s. 72).

W istocie wyniki te obrazują zarówno dostępność internetu, jak i problemy, w tym ryzyka, z którymi mierzą się młodzi ludzie konfrontujący się z innymi w sieci. W tym kontekście warto przytoczyć wyniki badania Sue Caton i Melanie Chapman (2016), które dokonały przeglądu literatury specjalistycznej dotyczącej badań nad korzystaniem z mediów społecznościowych przez osoby z niepełnosprawnością intelektualną. Autorki doszły do wniosku, że użytkownicy mają na ogół pozytywne doświadczenia w zakresie przyjaźni, rozwoju tożsamości społecznej, poczucia własnej wartości i zadowolenia. Jednakże istnieją bariery uniemożliwiające swobodny dostęp do mediów społecznościowych, stanowiące zarazem niejako swoistą ochronę dla użytkowników. Są to najczęściej trudności spowodowane umiejętnościami czytania, pisania i komunikacji, językiem (tzw. cyberetykietą), a nawet zwykłą dostępnością do odpowiedniego sprzętu.

Adi Sharabi i Malka Margalit (2011) badały ryzyko samotności i czynniki ochronne wśród izraelskiej młodzieży przejawiającej trudności w uczeniu się. Porównywano różne czynniki problemów w dwóch grupach: z trudnościami w uczeniu się i bez nich, czyli w grupie kontrolnej. Mierzone czynniki to samotność, komunikacja, nastrój, motywacja społeczna i nastawienie na osiągnięcia. Okazało się, że model samotności oznacza korzystanie z internetu do wspierania komunikacji interpersonalnej z przyjaciółmi i mniej intensywną samotność. Jednocześnie przyjaźnie online z osobami, które uczniowie znali tylko z sieci, oznaczały dotkliwą samotność. Ponadto nasilenie trudności w uczeniu się powoduje również zwiększone poczucie samotności. $Z$ kolei badanie Cristiny Jenaro i in. (2018) potwierdza, że młodzież i studenci z niepełnosprawnością intelektualną częściej korzystają z internetu w celach towarzyskich i rekreacyjnych niż edukacyjnych, co przekłada się na ryzyko niebezpiecznych zachowań (np. agresywnych). Zanotowano zarazem wyższe wskaźniki nadmiernego korzystania z technologii online (przesyłanie zdjęć, filmów, korzystanie z randek) wśród tych, którzy mają do nich dostęp niż w porównawczej grupie osób pełnosprawnych. 


\section{CYBERPRZEMOC}

Badania nad korzystaniem $\mathrm{z}$ sieci $\mathrm{w}$ grupach młodzieży niepełnosprawnej intelektualnie i tej bez problemów udowadniają, że zarówno pierwsza, jak i druga grupa korzysta z niej w tym samym stopniu i jest zaangażowana na podobnym poziomie. Różnice dotyczą czego innego. Robert Didden i in. (2009) przeprowadzili badanie nad cyberprzemocą wśród uczniów holenderskich szkół specjalnych. Kryterium doboru uczniów stanowił wynik testu ilorazu inteligencji wypełniany przed badaniem (granica to min. 50 pkt.), możliwości zrozumienia tekstu $\mathrm{w}$ celu wypełnienia kwestionariusza oraz sprawne posługiwanie się smartfonem lub komputerem stacjonarnym. U większości uczniów stwierdzono ADHD, w przypadku innych - spektrum autyzmu. Kwestionariusz dotyczył częstości korzystania ze smartfona lub komputera, a w najważniejszej części zaznaczano zdarzenia agresywne, zarówno te stosowane przez respondenta, jak i wobec niego; chodziło zatem o to, czy bywał też ofiarą (victimization). Chłopcy częściej angażowali się w zastraszanie za pośrednictwem telefonu komórkowego niż dziewczęta. Co ciekawe, $69 \%$ uczniów twierdziło, że ich rodzice nic nie wiedzą o ich działaniach w internecie. Oczywiście większość młodzieży korzystała z portali społecznościowych (67\%), pobierała pliki z muzyką, grała w gry online czy wyszukiwała informacji w celach edukacyjnych (30\%). Badanie pokazuje, że w ciągu ostatniego miesiąca uczniowie nikogo nie prześladowali w internecie, ale odsetki uczniów będących ofiarami przestępstw przynajmniej raz w tygodniu wahały się w granicach 5-12\% w zależności od formy stosowanej agresji. Odsetek uczniów, którzy dręczyli innych w sieci przynajmniej raz w tygodniu, był nieco niższy i zróżnicowany w przedziale 1-8\%. Wystąpiła istotna dodatnia korelacja między byciem ofiarą cyberprzemocy i sieciowym agresorem. Badacze zastanawiali się, czy w tej grupie badanej nie doszło do zbiegu okoliczności, gdzie uczniowie szkół specjalnych stanowią szczególną zbiorowość, w której zarówno atakują, jak i bywają oni ofiarami takich ataków. Jak się okazało dalej, takie zjawisko występuje także poza szkołą specjalną. Didden i in. stwierdzili też, że im częściej ktoś był prześladowany w internecie, tym mniej miał poczucia własnej wartości i zgłaszał bardziej depresyjne uczucia. Mimo to u uczniów z niepełnosprawnością intelektualną i rozwojową występuje nieco mniejsze prawdopodobieństwo, że będą ofiarami i równocześnie będą się znęcać nad kimś $\mathrm{w}$ internecie niż w grupach rówieśników niezdiagnozowanych jako upośledzeni.

Wydaje się więc, że istnieje podgrupa uczniów będących zarówno ofiarami cyberprzemocy, jak i agresorami. Nie jest do końca jasne, czym różni się ta grupa uczniów od innych i dlatego należy przyjrzeć się cechom socjodemograficznym. Badanie Diddena i in. (2009) wykazało istotne powiązania między cyberprzemocą i ilorazem inteligencji, rodzajem zaburzeń (ADHD, spektrum autyzmu), poczuciem własnej wartości i depresją oraz częstością korzystania z komputera. Stwierdzenie, że istnieje związek między emocjonalnymi a psychologicznymi problemami oraz wiktymizacją jest zgodne $z$ innymi badaniami dotyczącymi cyberbullyingu. Okazuje się, że ofiary internetowe zgłaszają znacznie więcej problemów psychologicznych (np. depresyjne uczucia, samotność, negatywne przekonanie o sobie) niż młodzież niezdiagnozowana i bez podobnych problemów. Na przykład Shunit Reiter i Noam Lapidot-Lefler (2007) potwierdzają takie wnioski, gdyż w ich badaniu ofiary zgłaszały znacznie częstsze odczucia emocjonalne i problemy interpersonalne 
niż tylko syndrom znęcania się ofiara - agresor. Stwierdzono też związek między częstością korzystania z komputera i cyberprzemocą, co potwierdziły badania Michelle Ybarra i Kimberly Mitchel (2004), gdzie częste nękanie i hejt online powiązano z częstym korzystaniem $\mathrm{z}$ internetu.

\section{ZACHOWANIA SEKSUALNE W INTERNECIE}

Claude Normand i François Sallafranque-St-Louis (2016) piszą, że do wykorzystywania seksualnego $\mathrm{w}$ internecie przyczynia się izolacja społeczna i samotność, a depresja i rozmowy na czacie zwiększają ryzyko bycia ofiarą molestowania. Wiele tych czynników ryzyka występuje częściej u młodzieży z niepełnosprawnościami niż w populacji ogólnej. Badania na próbie 114 szkół specjalnych wskazują na uczniów z IQ w przedziale 52-85, a $97 \% \mathrm{z}$ nich ma dostęp do internetu w domu, $41 \%$ ma komputer we własnym pokoju. Większość młodych używa go do pobierania muzyki lub grania, $43 \%$ wysyła lub odbiera e-maile, $27 \%$ publikuje dane osobowe o sobie w sieci, a $24 \%$ rozmawia przez internet (za: Didden i in., 2009). Tym niemniej korzyści i zagrożenia związane z korzystaniem z internetu przez młodzież z niepełnosprawnością intelektualną lub ze spektrum autyzmu wciąż nie są dobrze rozpoznane.

Według Normanda i Sallafranque-St-Louis (2016) internet kojarzy się na ogół z samoświadomością, poczuciem własnej wartości, siły i dobrobytem oraz rozwojem seksualnym młodzieży. Melissa Wells i Kimberly Mitchell (2013) opisują amerykańskie badanie Young Internet Safety Survey (YISS-3) prowadzone wśród młodzieży w przedziale 10-17 lat w 2010 r. Pokazuje ono, że młodzież niepełnosprawna fizycznie częściej niż sprawni rówieśnicy nawiązuje bliskie relacje online. Ponadto przedstawiciele młodzieży ze specjalnymi potrzebami edukacyjnymi (SPE) częściej niż pozostali respondenci wysyłają swoje zdjęcia do użytkowników spotykanych w sieci i angażują się w zachowania seksualne online. Autorki piszą dalej, że uczniowie szkół specjalnych są mniej skłonni od tych z populacji ogólnej do korzystania z mediów społecznościowych (68\% vs. $82 \%)$, do rozmów wideo ( $24 \%$ vs. $32 \%$ ) i rzadziej są nękani online (41\% vs. $49 \%)$. Jednak równie chętnie rozmawiają z osobami online ( $41 \%$ vs. $40 \%)$ i jest bardziej prawdopodobne, że częściej przejawiają zachowania seksualne (20\% vs. $13 \%)$.

Korzystanie z internetu nie jest zatem pozbawione zagrożeń, zwłaszcza dotyczących nagabywania seksualnego (sexual cybersolicitation). W badaniu YISS-3 wykazano ponadto, że 9\% internautów w wieku 10-17 było ofiarami niechcianego seksu (Jones, Mitchell, Finkelhor, 2012). Młodzież z SPE w badaniu YISS-3 była bardziej skłonna (14\%) do zgłaszania seksualnego nagabywania w internecie niż inne osoby młode (Wells, Mitchell, 2013). Ogólnokrajowe badanie młodzieży w Danii z 2008 r. zdaje się potwierdzać te wyniki, gdyż 5\% chłopców i 16\% dziewcząt w wieku 14-17 lat zgłosiło nagabywanie seksualne w internecie (Helweg-Larsen, Schutt, Larden, 2012).

Wykorzystywanie seksualne niekorzystnie wpływa na zdrowie psychiczne i funkcjonowanie młodych ludzi (Ybarra, Mitchell, 2004). Bywają oni zawstydzeni przez niegrzeczne komentarze seksualne lub nękanie w sieci, denerwują się i są przestraszeni propozycjami 
seksualnymi (Livingstone i in., 2011). Młodzież z SPE jest dwukrotnie bardziej wrażliwa na takie wiadomości niż osoby bez stwierdzonej niepełnosprawności (14 vs. 7\%) (Wells, Mitchell, 2013). W innym badaniu wykryto, że niska zdolność poznawcza była związana z ryzykownymi zachowaniami w internecie (Noll i in., 2013).

W literaturze opisuje się nagabywanie seksualne w internecie jako „akt popełniony przez drapieżnika (predator)”, który zachęca młodą osobę do rozmowy o seksie, ujawnienia danych osobowych o charakterze seksualnym lub angażowania się w zachowania seksualne w sieci (Ybarra, Mitchell, 2004). Według badań YISS odsetek młodych ofiar nagabywania seksualnego w internecie spadł z 19\% w 2000 r. do 9\% dziesięć lat później (Wells, Mitchell, 2013; Jones, Mitchell, Finkelhor, 2012). Zdaniem badaczy wynika to z większej świadomości i edukacji młodzieży i ich rodziców w zakresie bezpieczeństwa w sieci. Niemniej jednak nagabywanie notowano u większego odsetka młodzieży (28\%), która cechowała się określonymi czynnikami ryzyka jak przeszłe wykorzystywanie seksualne i fizyczne oraz konflikty z rodzicami (Wells, Mitchell, 2008). Ważne jest, że ofiarami nagabywania czy nękania seksualnego online częściej okazują się ofiary rzeczywistej przemocy seksualnej, np. molestowania, gwałtu, przemocy rodzicielskiej (tamże).

Niektórzy autorzy (np. Holt i in., 2010, za: Normand i Sallafranque-St-Louis, 2016) wskazują wprost na istnienie subkultury pedofilskiej i w związku z tym na agresywne nagabywanie seksualne w sieci. Ta koncepcja odnosi się do indywidualnego wywierania presji na młodą jednostkę, z którą agresor kontaktuje się bezpośrednio e-mailem, telefonicznie lub osobiście (Mitchell i in., 2004). 3\% młodzieży w badaniu YISS doświadczyło takiego rodzaju nagabywania. W duńskim badaniu połowa z 3707 nastolatków spotkała znajomych online twarzą w twarz, lecz bez negatywnych konsekwencji, to samo dotyczy 9\% dzieci w wieku 9-16 lat w całej Europie (Livingstone i in., 2011).

Osoby z niepełnosprawnością intelektualną lub rozwojową są zwykle bardzo podatne na wszelkie sugestie i mają niski poziom samostanowienia. Jak pisze Stanisław Kowalik (2007), to czyni je łatwym łupem osób wykorzystujących seksualnie. Od 61\% do 83\% kobiet i od 25\% do 32\% mężczyzn z niepełnosprawnością intelektualną deklaruje, że byli ofiarami wykorzystywania seksualnego (McCarthy, Thompson, 1997). Jeśli chodzi o jednostki ze zdiagnozowanym autyzmem, jest to ok. 16-25\% (Mandell i in., 2005).

W próbie 509 rodziców dzieci z autyzmem, $94 \% \mathrm{z}$ nich było przekonanych, że ich dziecko było ofiarą zastraszania w ciągu ostatniego roku (Little, 2002). Pewne cechy charakterystyczne dla jednostek z niepełnosprawnością intelektualną lub autyzmem narażają na większe ryzyko cierpień z powodu aktów agresji. Na przykład ograniczenia w zdolności przewidywania konsekwencji działań i zachowań, a także trudności w rozszyfrowaniu emocji innych ludzi wyjaśniają większe rozpowszechnienie agresji wobec nich, lecz także łatwiejsze wykorzystywanie seksualne, gdyż paradoksalnie również potrzebują oni życia emocjonalnego i zbliżeń z innymi. Kowalik zauważa dalej, że agresorzy wykorzystują brak zachowywania ogólnych etykiet i to, iż niepełnosprawni intelektualnie nie stawiają oporu, a dotyczy to zarówno zachowań hetero- jak i homoseksualnych (Kowalik, 2007).

Glynis Murphy i Ali O’Callaghan (2004) zaobserwowały, że osoby z niepełnosprawnością intelektualną i ze spektrum autyzmu zawierają mniej liczne znajomości o charakterze seksualnym niż ich typowo rozwijający się rówieśnicy. Ich badanie pokazuje zakres tej róż- 
nicy. Znajomość seksualna uczestników z niepełnosprawnością intelektualną nie była tak duża, jak w przypadku młodych rówieśników bez diagnozy. To ograniczenie wiedzy wydaje się dotyczyć wielu osób w obszarze związanym z seksualnością, takim jak ciąża, masturbacja, antykoncepcja, kontrola urodzeń, choroby przenoszone drogą płciową oraz prawne aspekty seksualności i homoseksualizmu (Murphy i O’Callaghan, 2004). Według autorek można zaobserwować tu brak formalnej i nieformalnej edukacji seksualnej u osób niepełnosprawnych intelektualnie wykorzystywanych seksualnie (przynajmniej u tych, które są w stanie zrozumieć określone zasady bezpieczeństwa). Bardziej nieformalna edukacja seksualna, rozmowy z rówieśnikami i ta czerpana z magazynów jest raczej niedostępna dla młodzieży z niepełnosprawnością intelektualną z powodu stygmatyzacji, większej izolacji społecznej i mniejszej ilości interakcji. Rodzice też dostarczają mniej informacji o seksualności swoim dzieciom. Ponadto, jak piszą Murphy i O’Callaghan, ci młodzi ludzie mają mniejsze możliwości nawiązania romantycznego związku i doświadczania seksu. Brak edukacji seksualnej i związanych z nią praw prowadzi do problemów ze zrozumieniem sytuacji dotyczącej świadomej zgody na zbliżenie, i stąd pojawia się nadużycie. Jak piszą Normand i Sallafranque-St-Louis, jest to fakt istotny, gdyż osoby z niepełnosprawnością intelektualną na ogół „nie interpretują pewnych sytuacji jako obraźliwych oraz pewnych zachowań ludzi jako niedopuszczalnych" (tamże).

\section{PODSUMOWANIE}

Przegląd badań nad korzystaniem z internetu przez młodzież z niepełnosprawnością intelektualną pozostawia wrażenie, że w Polsce i w innych krajach istnieje jak na razie niewielkie zainteresowanie pedagogów i opiekunów w tej sprawie (np. Noll i in., 2013). Konstatacja ta nie dotyczy badaczy, wszak podejmują oni badania korespondujące z próbami zagranicznymi (badania E. Krzyżak-Szymańskiej, red.; P. Plichty i in.). Należy przypomnieć, że badania tego rodzaju są dość trudne (de Groot, Kaal, Stol, 2019; Całek, 2020). Niemniej jednak przegląd ten wykazuje, że młodzi z niepełnosprawnością intelektualną są nękani seksualnie w internecie i nie mają na ogół odpowiedniego wsparcia od rodziców, którzy nie są o tym informowani lub nie interesują się kontaktami swoich dzieci. Pokazuje to często słabą więź emocjonalną między dzieckiem a rodzicem, nie tylko w badaniach polskich (Ybarra i Mitchell, 2004). Młodzi ludzie, którzy czują się samotni, odizolowani, niezrozumiani lub dostrzegają brak wsparcia, tworzą często podgrupy szczególnie podatne na ryzykowne korzystanie $\mathrm{z}$ internetu. $\mathrm{W}$ rezultacie częstsze konflikty na linii rodzic-dziecko narażają respondentów z niepełnosprawnością intelektualną dwa i pół razy częściej na ryzyko doświadczeń nagabywania seksualnego niż inne młode osoby (Wells i Mitchell, 2008). Młodzi niepełnosprawni są szczególnie narażeni na wykorzystywanie przez zdrowych w różnego rodzaju grach i cyberprzemocy. Dlatego wszelkie programy dotyczące integracji przez internet, skądinąd słuszne, powinny być opatrzone wieloma warunkami współpracy i opieki ze strony osób odpowiedzialnych za młodzież. Jest to temat rzadki i drażliwy, jednak wymagający szczególnej uwagi ze strony socjologów, psychologów, specjalistów disability studies czy również, jak się zdaje, projektantów i specjalistów mediów społecznościowych. 


\section{BIBLIOGRAFIA}

Całek, G. (2020). Wybrane problemy i dylematy etyczne w badaniach z udziałem rodziców dzieci z Zespołem Aspergera. Przegląd Socjologiczny, 69 (3), 151-167. https://doi. org/10.26485/PS/2020/69.3/7

Caton, S., Chapman, M. (2016). The use of social media and people with intellectual disability: A systematic review and thematic analysis. Journal of Intellectual \& Developmental Disability, 41 (2), 125-139. https://doi.org/10.3109/13668250.2016.1153052

Didden, R., Scholte, R.H.J., Korzilius, H., de Moor, J.M.H., Vermeulen, A., O’Reilly, M., Lang, R., Lancioni, G.E. (2009). Cyberbullying among students with intellectual and developmental disability in special education settings. Developmental Neurorehabilitation, 12 (3), 146-151. https://doi.org/10.1080/17518420902971356

Douma, J., Moonen, X., Noordhof, L., Ponsioen, A. (2012). Richtlijn Diagnostisch Onderzoek LVB: aanbevelingen voor het ontwikkelen, aanpassen en afnemen van diagnostische intstrumentenbij mensen met een licht verstandelijk beperking [Guideline diagnostic research mild intellectual disability: recommendations to develop, adjust and assess diagnostic instruments by people withmild intellectual disability]. Utrecht, Netherlands: Landelijk Kenniscentrum LVB.

Goffman, E. (2005). Piętno. Rozważania o zranionej tożsamości. Gdańskie Wydawnictwo Psychologiczne.

Groot de, R., Kaal, H.L., Stol, W.Ph. (2019). Studying problematic online behavior of adolescents with mild intellectual disabilities and borderline intellectual functioning: methodological and ethical considerations for data collection. International Journal of Qualitative Methods, 18, 1-10. https://doi:org/10.1177/1609406919857978

Helweg-Larsen, K., Schütt, N., Larsen, H.B. (2012). Predictors and protective factors for adolescent Internet victimization: results from a 2008 nationwide Danish youth survey. Acta Paediatrica, 101(5), 533-539. https://doi.org/10.1111/j.1651-2227.2011.02587.x

Holt, T.J., Blevins, K.R., Burkert, N. (2010). Considering the pedophile subculture online. Sexual Abuse: Journal of Research and Treatment, 22, 3-24. https:// doi/10.1177/1079063209344979

Jenaro, C., Flores, N., Cruz, M., Pérez, M.C., Vega, V., Torres, V.A. (2018). Internet and cel phone usage patterns among young adults with intellectual disabilities. Journal of Applied Research in Intellectual Disabilities, 31(2), 259-272. https://doi.org/10.1111/ jar. 12388

Jones, L.M., Mitchell, K.J., Finkelhor, D. (2012). Trends in youth Internet victimization: findings from three youth Internet safety surveys 2000-2010. Journal of Adolescent Health, 50(2), 179-186. https://doi.org/10.1016/j.jadohealth.2011.09.015

Kowalik, S. (2007). Psychologia rehabilitacji. Wydawnictwa Akademickie i Profesjonalne.

Krzyżak-Szymańska, E. (red.) (2019). Charakterystyka zjawiska problemowego używania internetu oraz telefonu komórkowego przez młodzież uczaca się z niepełnosprawnościa intelektualna w stopniu lekkim, Raport końcowy: zad. 5.5 Narodowego Programu Zdrowia. Ministerstwo Zdrowia. 
Little, L. (2002). Middle-class mothers' perceptions of peer and sibling victimization among children with Asperger's syndrome and nonverbal learning disorders. Issues in Comprehensive Pediatric Nursing, 25(1), 43-57. https://doi.org/10.1080/014608602753504847

Livingstone, S., Haddon, L., Görzig, A., Ólafsson, K. (2011). Risks and Safety on the Internet: The Perspective of European Children. Full Findings and policy implications from EU Kids Online survey of 9-16 year olds and their parents in 25 countries. London School of Economics \& Political Science. http://eprints.lse.ac.uk/33731/1/Risks\%20and\%20safety\%20 on\%20the\%20internet\%28lsero\%29.pdf

Maciąg, R. (2021). Socjalizacja i wpływ Internetu na zdrowie młodzieży. W: M. Jagodzińska, M. Marcysiak, B. Ostrowska, E. Wiśniewska, M. Zagroba (red.), Wokół człowieka. Problemy pielegniarstwa, pedagogiki, pracy socjalnej. T. VI., Wydawnictwo Państwowej Uczelni Zawodowej im. I. Mościckiego w Ciechanowie (w druku).

Mandell, D.S., Walrath, Ch.M., Manteuffel, B., Sgro, G., Pinto-Martin, J.A. (2005). The prevalence and correlates of abuse among children with autism served in comprehensive community-based mental health settings. Child Abuse \& Neglect, 29(12), 1359-1372. https://doi.org/10.1016/j.chiabu.2005.06.006

McCarthy, M., Thompson, D. (1997). A prevalence study of sexual abuse of adults with intellectual disabilities referred for sex education. Journal of Applied Research in Intellectual Disabilities, 10(2), 105-124. https://doi.org/10.1111/j.1468-3148.1997.tb00012.x

Mróz, A. (2018). Konstruowanie tożsamości osobistej jako adaptacyjne wyzwanie dla osób intelektualnie nietypowych. Wnioski z przeglądu badań psychologicznych i socjologicznych. Psychologiczne Zeszyty Naukowe, 1, 193-202. http://cejsh.icm.edu.pl/cejsh/element/ bwmeta1.element.desklight-50b58104-7650-423b-8905-70f71bbc2c6c

Murphy, G.H., O'Callaghan, A.C. (2004). Capacity of adults with intellectual disabilities to consent to sexual relationships. Psychological Medicine, 34(7), 1347-1357. https://doi. org/10.1017/S0033291704001941

Noll, J.G., Shenk, Ch.E., Barnes, J.E., Haralson, K.J. (2013). Association of maltreatment with high-risk Internet behaviors and offline encounters. Pediatrics, 131(2), e510-e517. https://doi.org/10.1542/peds.2012-1281

Normand, C.L., Sallafranque-St-Louis, F. (2016). Cybervictimization of Young People with an Intellectual or Developmental Disability: Risks Specific to Sexual Solicitation. Journal of Applied Research in Intellectual Disabilities, 29(2), 99-110. https://doi.org/10.1111/jar.12163

Plichta, P. (2017). Socjalizacja i wychowanie dzieci i młodzieży z niepełnosprawnościa intelektualna w erze cyfrowej. Wydawnictwo Adam Marszałek.

Reiter, S., Lapidot-Lefler, N. (2007). Bullying among special education students with intellectual disabilities: Differences in social adjustment and social skills. Intellectual and Developmental Disabilities, 45(3), 174-181. https://doi.org/10.1352/1934-9556(2007)45[174:BASESW]2.0.CO;2

Seale, J., Chadwick, D. (2017). How does risk mediate the ability of adolescents and adults with intellectual and developmental disabilities to live a normal life by using the Internet? Cyberpsychology: Journal of Psychosocial Research on Cyberspace, 11(1). https://doi. org/10.5817/CP2017-1-2 
Sharabi, A., Margalit, M. (2011). The mediating role of Internet connection, virtual friends, and mood in predicting loneliness among students with and without learning disabilities in different educational environments. Journal of Learning Disabilities, 44(3), 215-227. https://doi.org/10.1177\%2F0022219409357080

Watson, N. (2002). Well, I know this is going to sound very strange to you, but I don't see myself as a disabled person: identity and disability. Disability \& Society, 17(5), 509-527. https://doi.org/10.1080/09687590220148496

Wells, M., Mitchell, K.J. (2008). How do high-risk youth use the Internet? Characteristics and implications for prevention. Child Maltreatment, 13(3), 227-234. https://doi.org/10.1177\%2F1077559507312962

Wells, M., Mitchell, K.J. (2013). Patterns of Internet use and risk of online victimization for youth with and without disabilities. Journal of Special Education, 20, 1-10. https://doi. org/10.1177\%2F0022466913479141

Ybarra, M.L., Mitchell, K.J. (2004). Youth engaging in online harassment: Associations with caregiver-child relationship. Journal of Adolescence, 27(3), 319-336. https://doi. org/10.1016/j.adolescence.2004.03.007

Żuchowska-Skiba, D. (2020). Wykluczenie cyfrowe osób z niepełnosprawnościami - perspektywy badawcze. W: G. Całek, J. Niedbalski, D. Żuchowska-Skiba (red.), Jak badać zjawisko niepetnosprawności. Szanse i zagrożenia założeń teoretycznych i metodologicznych studiów nad niepełnosprawnością (s. 195-212). Wydawnictwo Uniwersytetu Łódzkiego. https://dspace.uni.lodz.pl/handle/11089/33197 